\title{
Diet of the red shrimp Pleoticus muelleri (Bate, 1888) in Patagonian fishing grounds, Argentine
}

\author{
Dieta del langostino Pleoticus muelleri (Bate, 1888) en fondos \\ de pesca patagónicos, Argentina \\ Ana Roux ${ }^{1}$, Rubén Piñero ${ }^{1}$, Paula Moriondo ${ }^{1}$ and Mónica Fernández ${ }^{1}$ \\ ${ }^{1}$ Instituto Nacional de Investigación y Desarrollo Pesquero (INIDEP), \\ Paseo Victoria Ocampo 1, B7602HSA, Mar del Plata, Argentina \\ anaroux@inidep.edu.ar
}

\begin{abstract}
Resumen.- Se analizó el contenido estomacal de 2.157 langostinos Pleoticus muelleri de los fondos de pesca patagónicos, en Argentina. Las muestras provinieron de 40 lances realizados durante una campaña de investigación del BIP Capitán Oca Balda, del INIDEP (junio, 2003) y de los buques comerciales Arbumasa XVI (mayo 2003) y Arbumasa XV (julio 2003), entre los $43^{\circ} \mathrm{S}$ y $47^{\circ} \mathrm{S}$. El objetivo de este trabajo fue determinar la vinculación entre la composición de la dieta del langostino y las comunidades bentónicas de los fondos de pesca. Asimismo se consideró la relación entre la dieta y la talla. La ocurrencia de los ítems alimentarios alcanzó el 94\% de los estómagos de P. muelleri con diferentes grados de repleción. Los ítems alimentarios correspondieron a diez taxa. Crustáceos, poliquetos y moluscos fueron los ítems más importante y abundantes, estando representados en un $100 \%$
\end{abstract}

\section{Introduction}

The red shrimp Pleoticus muelleri (Bate, 1888) is abundant in Argentinean waters and represents one of the most important fisheries in the Argentine Sea (Bertuche et al. 2000). Owing to its commercial interest a wide range of biological and ecological studies on this shrimp species has been developed (Angelescu \& Boschi 1959 Boschi \& Angelescu 1962, Albertó et al. 1993).

The Patagonian red shrimp is an ecologically important benthic predator (Roux 1999). Crustaceans, mollusks and polychaetes are the main prey items. Feeding behavior is similar to other peneid shrimps from Australia, the Gulf of Carpentaria (Wassenberg \& Hill 1987, 1993), Moreton Bay (Hill \&Wassenberg 1987) and some crangonid species of the Irish Sea (Oh et al. 2001). Studies on peneidos diet have evidenced that shrimps are omnivorous and carnivores in coastal habitats and some species exert a direct influence on the abundance of small benthic macrofauna (Stoner \& Zimmerman 1988).

This study analyzed the diet composition of the Patagonian red shrimp in its natural habitat. The de los estómagos. La diversidad trófica (H'; índice de ShannonWiener), presentó valores entre 1,45 y 2,48 ; el $60 \%$ de los valores fue superior a 2. La uniformidad dietaria ( $\mathrm{J}$ '; índice de Pielou) presentó valores que indicaron una buena y variada disponibilidad de alimento, consecuencia de la composición y estructura de la comunidad bentónica de los fondos. La dieta de P. muelleri consistió predominantemente en tres categorías de organismos de fondo: 1) demersales (miscidáceos, eufáusidos, decápodos), 2) epifaunales (anfípodos, isópodos, cumáceos, gasterópodos) y 3) infaunales (bivalvos, poliquetos, foraminíferos, nematodos). Se concluye que $P$. muelleri es un depredador importante sobre organismos bentónicos.

Palabras clave: Conducta de alimentación, ítemes presa, Patagonia

relationships between diet and food availability, considering the benthic community structure in different areas of the Patagonian fishing grounds, and the diet variations with specimen sizes were determined.

\section{Material and methods}

Stomach contents of 2,157 Patagonian red shrimps were analyzed. Specimens were obtained from 40 diurnal hauls during the research cruise OB-05/03 (June 2003) performed by FRV 'Capitán Oca Balda' (INIDEP) and from commercial trawling fishery vessels 'Arbumasa XVI' (May 2003) and 'Arbumasa XV' (July 2003) (Fig. 1). All individuals were collected between 43 and $108 \mathrm{~m}$ depth between $43^{\circ} \mathrm{S}$ to $47^{\circ} \mathrm{S}$.

Shrimps were fixed in 10\% buffered formalin solution. Prey items from stomach contents were determined to the lowest taxonomical level when possible. Carapace length (CL), sex and condition of stomach fullness of each specimen were registered. For the foregut content analyses shrimps were grouped into four size classes on the basis of CL. The degree of stomach fullness was assessed visually applying a relative 


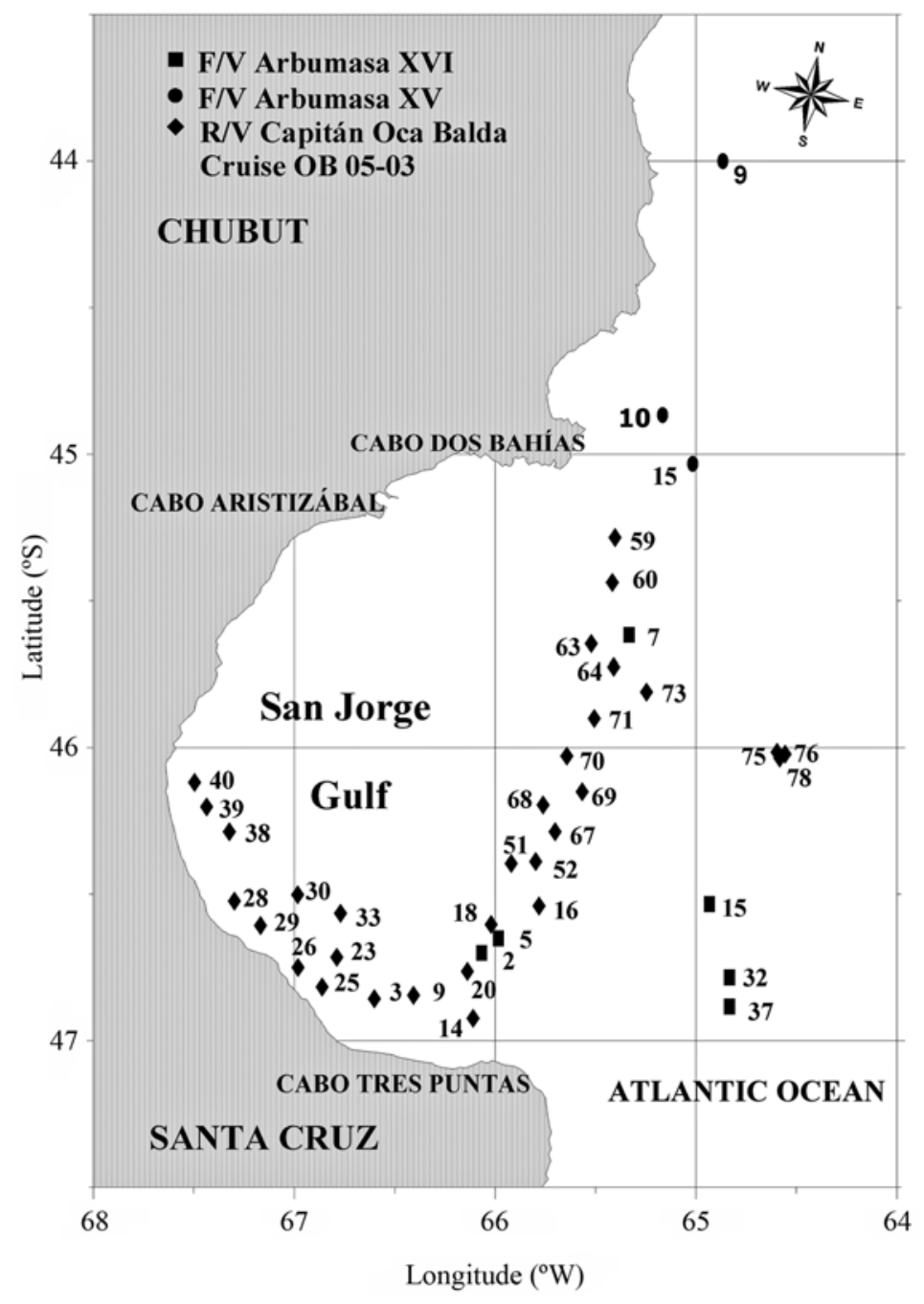

Figure 1

Geographical location of the fishing hauls

Localización geográfica de los lances de pesca

fullness empiric scale: $0=0 \%$ (empty), $1=25 \%, 2=$ $50 \%, 3=75 \%$ and $4=100 \%$ (full) (Prejs 1981). The food content of 60 foreguts (30 males and 30 females) per haul was analyzed following Boschi (1969) and Prejs (1981). The occurrence (O) of food items was estimated and expressed in percentage.

Trophic diversity $\left(\mathrm{H}^{\prime}\right)\left(\mathrm{H}^{\prime}=-\Sigma \mathrm{P}_{\mathrm{i}}\left(\ln \mathrm{P}_{\mathrm{i}}\right)\right.$ in the diet was calculated according to the Shannon-Wiener Index (Zar 1996).

Diet evenness was calculated by the Pielou Index (J') (J' = H' / H' ${ }_{\text {máx }}$ ) (Legendre \& Legendre 1979). Dietary affinity among size classes (items $\mathrm{x}$ size class matrix) and geographic areas (items $x$ hauls matrix) was established by cluster analysis (Bray-Curtis similarity index, UPGMA technique). ANOVA test was applied to determine what item had a significantly different frequency between the geographic sectors (Zar 1996). Primer 5 (Clark \& Warwick 2001) and STATISTICA Software 6.0 (Statsoft 2001) software were used for the analyses.

\section{Results}

A total of 2,157 stomachs were examined. They presented an item occurrence of $94 \%$ although with different repletion degrees. Thirty food items belonging to ten taxa were determined. Crustaceans, annelid polychaetes and 


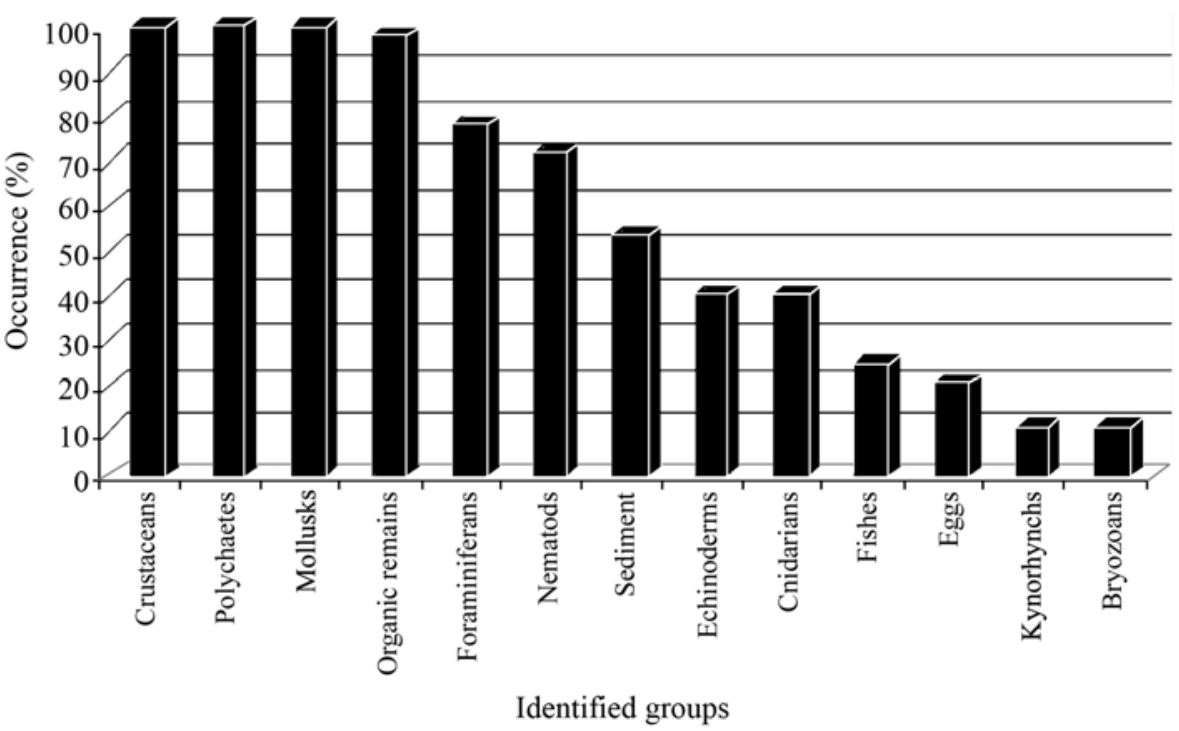

Figure 2

Occurrence of the identified groups in the stomach content analysis of $P$. muelleri

Ocurrencia de los grupos identificados en el análisis del contenido estomacal de $P$. muelleri

mollusks were the most frequent food items being present in $100 \%$ of the examined foreguts (Fig. 2, Table 1). Other preys occurred in low frequencies.

The number of food items per stomach ranged between 6 and 20, with a mean of 13. The trophic diversity ranged between 1.45 and 2.48 , and $60 \%$ of them had values $>2$.

Crustaceans represented the major food items, including: ostracods, cumaceans, copepods, euphausiids, mysids, gammarid and hyperid amphipods, isopods, crabs as well as decapods. Entire and recently ingested specimens of the decapod Peisos petrunkevitchi Burkenroad, 1945 were found occupying the whole stomach cavity. The number of gammarid amphipods per stomach ranged from 1 to 5 individuals.

Abundant polychaete remains in different digestion degrees were found. Entire specimens, jaws, chaetae and free and aggregated elytra allowed identifying them as belonging to the families Aphroditidae, Polynoidae, Eunicidae, Lumbrineridae and Maldanidae.

Bivalves were mainly juveniles. They were extremely small, with a length range between $0.5 \mathrm{~mm}$ to $1.8 \mathrm{~mm}$. Smashed valve remains with soft tissues were also found. Entire small clams were observed in some stomachs. The clams Nuculana sulculata (Cothouy, 1852) and Nucula puelcha d'Orbigny, 1842 were frequent and abundant prey items. Naticidae gastropod opercula and embryos were sorted and identified, as well as remains of micromollusks shells (Balcis sp., Odostomia sp.). Ingestion of cephalopods was assessed through the identification of Semirossia tenera (Verril, 1880) tentacles and other species beaks.

Echinoderm carapace and spine remains corresponded to the echinoid Pseudoechinus magellanicus (Philippi, 1857), while holothurian spicules belonged to Hemioedema spectabilis (Ludwig, 1882) and Taeniogyrus contortus (Ludwig, 1874). Ophiuroid remains mainly consisted of discs and arms of Amphiura Forbes, 1842.

Most of the registered pluriloculated benthic foraminiferan forms belonged to Quinqueloculina d'Orbigny, 1826 and Globigerina (Lippert, 1878) species.

Several minor groups were also identified. Tanaids were scantily represented in number of specimens as well as species; the hydrozoa families Campanulariidae and Sertulariidae were present in foregut contents; the nematodes belonged to the free living forms Adenophorea. Small vertebrae and spines of small fish were infrequent; kinorhynchs specimens of Echinoderes Claparede, 1863 were also present; colonies of the bryozoans Bowerbankia Farre, 1837, Bugula Oken, 1815 and Cellaria Ellis \& Solander, 1786 as well as unidentified eggs were scarce. 


\section{Table 1}

Food items identified in the analyzed stomachs of $P$. muelleri $(\mathrm{O}(\%)$ : Occurrence)

Items alimentarios identificados en los estómagos analizados de P. muelleri (O (\%): Ocurrencia)

\begin{tabular}{|c|c|c|c|}
\hline \multicolumn{3}{|c|}{ Food item } & $\frac{\mathrm{O}(\%)}{100}$ \\
\hline Crustaceans & $\begin{array}{l}\text { Amphipods } \\
\text { Ostracods } \\
\text { Cumaceans } \\
\text { Isopods } \\
\text { Euphausiids } \\
\text { Mysids } \\
\text { Decapods } \\
\text { Copepods } \\
\text { Larvae cypris }\end{array}$ & $\begin{array}{l}\text { Eufausia lucens } \\
\text { Pleoticus muelleri } \\
\text { Peisos petrunkevitchi }\end{array}$ & $\begin{array}{l}100 \\
95 \\
12.5 \\
75 \\
85 \\
65 \\
20 \\
62.5 \\
22.5 \\
50 \\
15 \\
52.5 \\
2.5\end{array}$ \\
\hline Polychaetes & & $\begin{array}{l}\text { Aphroditidae } \\
\text { Polynoidae } \\
\text { Eunicidae } \\
\text { Lumbrineridae } \\
\text { Maldanidae }\end{array}$ & 100 \\
\hline Mollusks & $\begin{array}{l}\text { Bivalves } \\
\text { Gastropods } \\
\text { Cephalopods }\end{array}$ & $\begin{array}{l}\text { Nucula puelcha } \\
\text { Nuculana sulculata } \\
\text { Balsis } \\
\text { Odostomia } \\
\text { Semirossia tenera }\end{array}$ & $\begin{array}{l}100 \\
100 \\
25 \\
72.5\end{array}$ \\
\hline Echinoderms & $\begin{array}{l}\text { Ophiuroids } \\
\text { Echinoids } \\
\text { Asteroids } \\
\text { Holothurians }\end{array}$ & $\begin{array}{l}\text { Amphiura } \\
\text { Pseudechinus magellanicus } \\
\text { Hemioedema spectabilis } \\
\text { Taeniogyrus contortus }\end{array}$ & $\begin{array}{r}40 \\
30 \\
85 \\
5 \\
5\end{array}$ \\
\hline $\begin{array}{l}\text { Nematods } \\
\text { Tanaids } \\
\text { Forminiferans }\end{array}$ & & $\begin{array}{l}\text { Adenophorea } \\
\text { Quinqueloculina } \\
\text { Globigerina }\end{array}$ & $\begin{array}{l}72.5 \\
25 \\
77.5\end{array}$ \\
\hline $\begin{array}{l}\text { Kynorhinchs } \\
\text { Hydrozoa }\end{array}$ & & $\begin{array}{l}\text { Echinoderes } \\
\text { Campanulariidae } \\
\text { Sertularidae }\end{array}$ & $\begin{array}{l}12.5 \\
40\end{array}$ \\
\hline Bryozoa & & $\begin{array}{l}\text { Bowerbankia } \\
\text { Bugula } \\
\text { Cellaria }\end{array}$ & 12.5 \\
\hline $\begin{array}{l}\text { Fishes } \\
\text { Eggs (indet.) } \\
\text { Remains } \\
\text { Sediment }\end{array}$ & & & $\begin{array}{l}25 \\
20 \\
97.5 \\
52.5\end{array}$ \\
\hline
\end{tabular}


Many stomachs were full of preys with a small amount of sand, probably ingested during the feeding process. Sand was frequent in stomachs with low repletion degree.

The 2,157 stomachs analyzed showed different repletion degrees, predominating degrees 1 and $2(31 \%$ and $34 \%$, respectively). Degree 3 was assessed in $22 \%$ of the stomachs while lower values corresponded to degrees 4 and 0 (7\% and 6\%, respectively).

A high affinity was determined among annelids, crustaceans and mollusks items by the UPGMA (Fig. 3A)

According to the analyzed stomach contents of shrimps two main geographic sectors were conformed. These sectors belonged to the southern area and northern mouth of San Jorge Gulf and southern mouth and external waters of San Jorge Gulf and littoral of Chubut. Significant differences $(P<0.05)$ in diet composition between sectors were observed (Fig. 3B). Crustaceans, mollusks, annelids, nematodes, cnidarians and foraminifers were the most significantly different items.

Diet composition showed high similarity in relation to the size of shrimp specimens (size range from $16 \mathrm{~mm}$ to $55 \mathrm{~mm}$ ), mainly between bigger sizes and in smaller ones (Fig. 3C).

\section{Discussion}

Our results agreed with Roux (1999) in the sense that Pleoticus muelleri feeds preferentially on benthic organisms. On the contrary, previous studies indicated that it feeds on detritus (Angelescu \& Boschi 1959, Boschi \& Angelescu 1962, Albertó et al. 1993). This behavior was also observed in other peneidos and caridean species previously defined as predators of benthic invertebrates (Figueras 1986, Wassenberg \& Hill 1987, Dall et al. 1990, Capitoli et al. 1994, Guerao 1995, Guerao \& Ribera 1996). Dall et al. (1990) described the peneidos as «opportunistic omnivores» without a selective feeding habit. Lindner \& Cook (1970) observed that Peneus setiferus (Linnaeus, 1767) showed selectivity in its feeding habits. This species searches among the sand grains preys with its pereiopods, conducting them towards the jaws selecting mainly polychaetes. This fact was also observed in other three omnivorous species of prawns of the United States coasts.

Crustaceans, polychaetes and mollusks characterized the diet composition of the Patagonian red shrimp of San Jorge Gulf. These observations agree with those of Dall et al. (1990), Figueras (1986) and Wassenberg \& Hill (1987) for other peneidos and palemonies species.

Regional differences in shrimp diet are mainly related to the benthic community structure, habitat and preys availability. Trophy diversity values indicated considerable and varied food availability, due to the diversified benthic community of the bottoms (Roux et al. 1995, Roux \& Fernández 1997, Fernández et al. 2003). In the southern area and the northern mouth of San Jorge Gulf, benthic communities are mainly characterized by annelids and bivalves whereas in the southern mouth and external waters of the gulf and littoral of Chubut, crustaceans and bryozoans are common (Roux et al. 1995, Roux \& Fernández 1997, Fernández et al. 2003, 2007).

In the present study we distinguished three bottom dwelling categories for the diet composition of Pleoticus muelleri: 1) demersal organisms such as mysids, euphausiids, decapods and fishes 2) epifaunal organisms which include amphipods, cumaceans, isopods and gastropods and 3) infaunal organisms like bivalves, foraminiferans and nematodes. The diet composition was always dominated by crustaceans, polychaetes and mollusks, which are the main components of the infauna and epifauna, stressing the close trophy relationship to the benthic community. General characteristics of the shrimp diet are similar to crangonid species of the Irish Sea (Oh et al. 2001).

Crustaceans were important in the shrimp diet, evidenced by the higher affinity for benthic organisms, the abundance of gammarid amphipods, ostracods, cumaceans and decapods and the contribution of the nearbottom euphausiids, mysids and copepods. Mollusks were mainly represented by two dominant species of bivalves inhabiting soft bottoms, Nuculana sulculata and Nucula puelcha (Roux et al. 1995, Roux \& Fernández 1997).

The higher affinity of the smallest sizes against the biggest ones reflects ontogeny changes in the diet. Differences in diet are evident with the increase of size, consuming bigger and harder preys. Similar observations were reported for Palaemon adspersus Rathke, 1837 and $P$. xiphias Risso, 1816, in which the consumption of mollusks increased with the size of shrimps (Guerao 1995, Guerao \& Ribera 1996). Figueras (1986) observed that in Palaemon adspersus and P. serratus Pennant, 1777 , the increment of prey sizes was directly related to the increment of the body size of shrimp, which was also related to the stomach broadening and strength of the mouth pieces.

During the present study we also observed that Pleoticus muelleri developed diurnal feeding activity. In most cases, preys were recently ingested and the digestion was incipient. A similar observation was carried out by Roux (1999) in specimens captured in 24 hauls conducted by research cruises during 1996 in the San Jorge Gulf. 

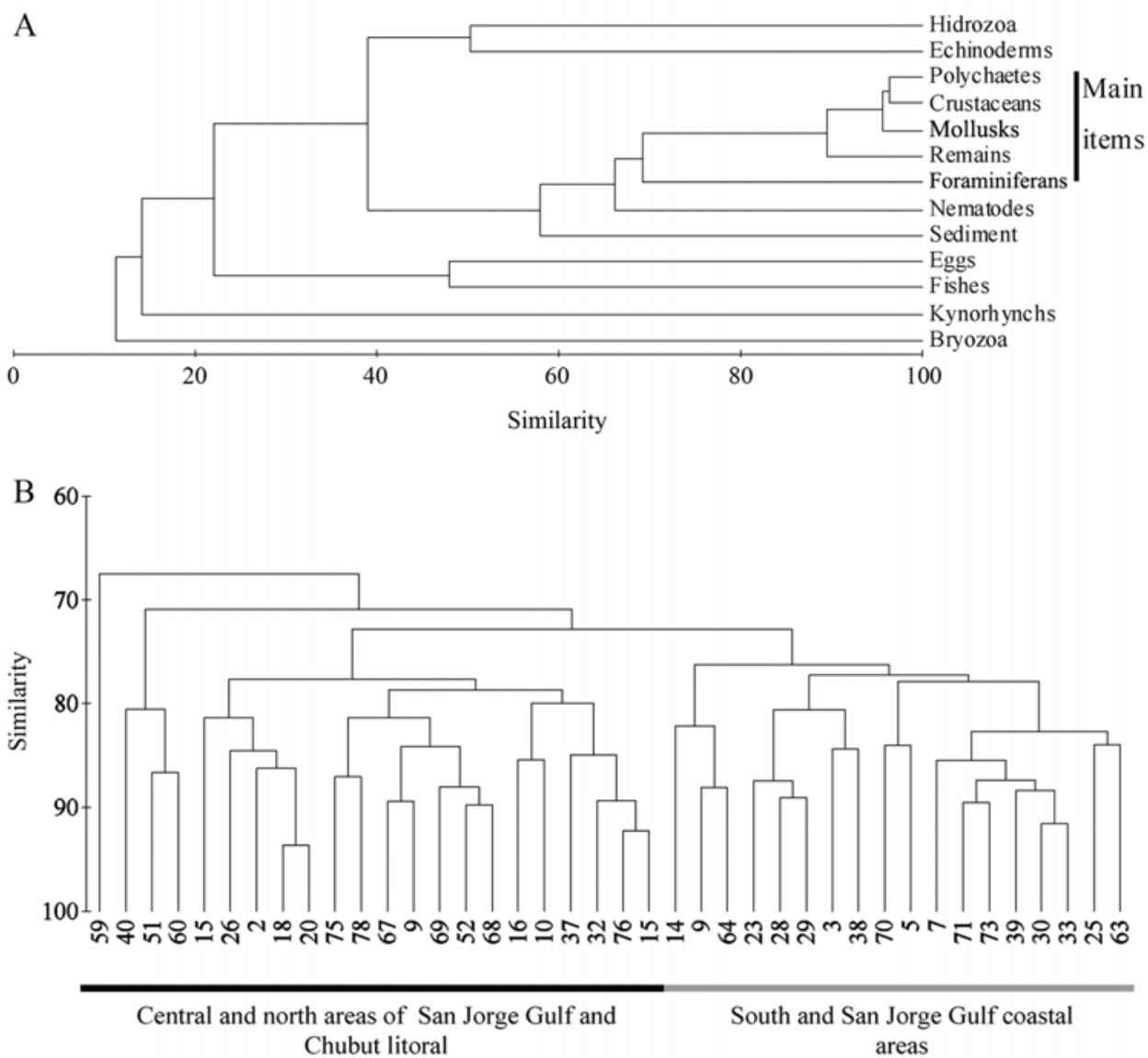

C

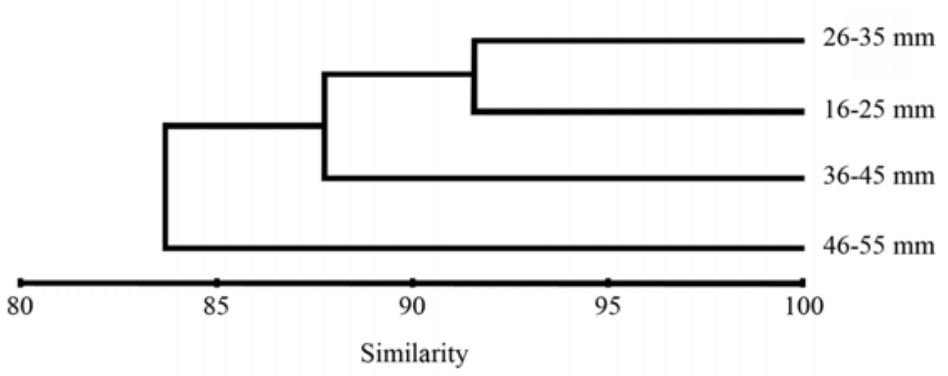

Figure 3

P. muelleri. A. Alimentary item affinity (Bray-Curtis, UPGMA), B. Areas identified by alimentary item affinity (Bray-Curtis, UPGMA), C. Size affinity in the diet composition

P. muelleri. A. Afinidad entre items alimentarios (Bray-Curtis, UPGMA), B. Áreas definidas por afinidad de la dieta (Bray-Curtis, UPGMA), C. Afinidad de tallas de acuerdo a la composición de la dieta 


\section{Literature cited}

Albertó E, R Scrosati \& G Díaz. 1993. Alimentación del langostino Pleoticus muelleri (Crustacea, Decapoda) del Golfo San Jorge, Argentina. Gayana Zoología 57(2): 279284.

Angelescu V \& E Boschi. 1959. Estudio biológico pesquero del langostino de Mar del Plata en conexión con la Operación Nivel Medio. Servicio de Hidrografía Naval, Sección Marina, Público H 1017: 1-135.

Bertuche D, C Fischbach, A Roux, M Fernández \& R Piñero. 2000. Langostino (Pleoticus muelleri). In: Bezzi S, R Akselman \& E Boschi (eds). Síntesis del estado de las pesquerías marítimas argentinas y de la Cuenca del Plata. Años 1997-1998, con una actualización de 1999, 388 pp. Publicaciones Especiales, Instituto Nacional de Investigación y Desarrollo Pesquero (INIDEP), Mar del Plata.

Boschi E. 1969. Estudio biológico pesquero del camarón Artemesia longinaris Bate de Mar del Plata. Boletín del Instituto de Biología Marina 18: 1-47.

Boschi E \& V Angelescu. 1962. Descripción de la morfología externa e interna del langostino con algunas aplicaciones de índole taxonómica y biológica. Boletín del Instituto de Biología Marina 1:1-73.

Capitoli R, A Bager \& M Ruffino. 1994. Contribuçao ao conhecimento das relaçoes tróficas bentônico-demersais nos fundos de pesca do camarao Artemesia longinaris Bate, na regiao da Barra da Lagoa dos Patos, RS, Brasil. Nauplius 2: 53-74.

Clark K \& R Warwick. 2001. Change in marine communities: an approach to statistical analysis and interpretation, 165 pp. Primer-E, Plymouth.

Dall W, B Hill, P Rothisberg \& D Staples. 1990. The Biology of Penaeidae. In: Blaxter JHS \& AJ Southward (eds). Advances in Marine Biology 27: 1-489, Academic Press, London.

Fernández M, D Cucchi-Colleoni, A Roux, A Marcos \& E Fernández. 2007. Caracterización físico-química del sistema bentónico en el sector sur del Golfo San Jorge, Argentina. Revista de Biología Marina y Oceanografía 42(2): $177-192$

Fernández M, A Roux, E Fernández, J Caló, A Marcos \& H Aldacur. 2003. Grain size analysis of surficial sediments from Golfo San Jorge, Argentina. Journal of the Marine Biological Association of the United Kingdom 83: 11931197.

Figueras A. 1986. Alimentación de Palaemon adspersus (Rathke, 1837) y Palaemon serratus (Pennant, 1777) (Decapoda: Natantia) en la Ría de Vigo (N.O. España). Cahiers de Biologie Marine 27: 77-90.
Guerao G. 1995. Locomotor activity patterns and feeding habits in the prawn Palaemon xiphias (Crustacea: Decapoda: Palaemonidae) in Alfacs Bay, Ebro Delta (northwest Mediterranean). Marine Biology 122(1): 115-119.

Guerao G \& C Ribera. 1996. Locomotor activity and feeding habits in the prawn Palaemon serratus (Pennant, 1777) (Decapoda, Palaemonidae) in the Alfacs Bay, Ebro Delta, Spain. Crustaceana 69(1):101-112.

Hill B \& T Wassenberg. 1987. Feeding behavior of adult Tiger Prawn, Penaeus esculentus, under laboratory conditions. Australian Journal of Marine and Freshwater Research 38: 183-190.

Lindner M \& H Cook. 1970. Synopsis of biological data in the white shrimp Penaeus setiferus (Linnaeus) 1767. FAO Fisheries Report 57: 1439-1469.

Oh C, R Hartnoll \& R Nash. 2001. Feeding ecology of the common shrimp Cragnon cragnon in Port Erin Bay, Isle of Man, Irish Sea. Marine Ecology Progress Series 214: 211-223.

Prejs A. 1981. Métodos para el estudio de los alimentos y las relaciones tróficas de los peces, 129 pp. Ed. Universidad Central de Venezuela, Caracas.

Roux A. 1999. Composición de la dieta de Pleoticus muelleri del Golfo San Jorge, Argentina. Libro de Resúmenes ampliados Tomo I: 65-66. COLACMAR, Trujillo.

Roux A \& M Fernández. 1997. Caracterización de los fondos de pesca del langostino patagónico Pleoticus muelleri en el Golfo San Jorge y litoral de la provincia de Chubut, Argentina. Serie Informes Técnicos INIDEP 13: 1-28.

Roux A, M Fernández \& C Bremec. 1995. Estudio preliminar de las comunidades bentónicas de los fondos de pesca del Golfo San Jorge (Argentina). Ciencias Marinas 21(2): 295310

Statsoft.2001. STATISTICA Software, versión 6.0. StatSoft, Inc, Tulsa.

Stoner A \& R Zimmerman. 1988. Food pathways associated with penaeid shrimps in a mangrove-fringed estuary. Fishery Bulletin 86(3): 543-551.

Wassenberg T \& B Hill. 1987. Natural diet of the tiger prawns Penaeus esculentus and P. semisilcatus. Australian Journal of Marine and Freshwater Research 38: 169-182.

Wassenberg T \& B Hill. 1993. Diet and feeding behaviour of juvenile and adult banana prawns Penaeus merguiensis in the Gulf of Carpentaria, Australia. Marine Ecology Progress Series 94: 287-295.

Zar J. 1996. Bioestatistical analysis, 662 pp. Prentice-Hall, Upper Saddle River. 